\title{
ANALISIS KOMPETENSI \& KESIAPAN MAHASISWA PGSD DALAM PENGELOLAAN PEMBELAJARAN ABK DI SEKOLAH INKLUSI
}

\author{
Endang Poerwanti* \\ Nawang Sulistyani
Pendidikan Guru Sekolah Dasar, Fakultas Keguruan dan Ilmu Pendidikan, Universitas Muhammadiyah Malang
Jl. Raya Tlogomas No. 246 Malang, Indonesia
*E-mail:endang_p@umm.ac.id

Artikel diterima: 16 Februari 2021; disetujui: 26 Mei 2021

\begin{abstract}
One of the superior profiles that prospective elementary school teacher students should have is competence in providing inclusive education services. The importance of these competencies is analyzed in this study to describe the competence and readiness of University Muhammadiyah Malang Elementary School Teacher Education Study Program students in managing ABK learning in inclusive schools. The mixed-method research with research subjects was 300 students, five lecturers, and one East Java inclusion development team. The research data were collected through a group discussion forum, questionnaires, and documentation which were analyzed using descriptive qualitative and quantitative techniques. From the research results obtained the formulation of ten competencies in the management of inclusive learning that should be mastered by prospective elementary school teacher students. The results also showed that the majority of UMM PGSD Study Program students had good readiness in mastering the ten competencies, including $85 \%$ mastering criteria $1,2,3,4,7$, and 8 ; $65 \%$ mastered criteria 5 and 6; 80\% mastered criteria 9 and 10.
\end{abstract}

Keywords: learning management; children with special needs; elementary school teacher education students

\begin{abstract}
Abstrak: Salah satu profil unggul yang hendaknya dimiliki mahasiswa calon guru SD adalah kompetensi dalam memberikan layanan pendidikan inklusi. Pentingnya kompetensi tersebut dianalisis dalam penelitian ini dengan tujuan untuk mendeskripsikan kompetensi dan kesiapan mahasiswa Prodi PGSD Universitas Muhammadiyah Malang dalam pengelolaan pembelajaran ABK di sekolah inklusi. Penelitian ini menggunakan mix method dengan subjek penelitian adalah 300 mahasiswa, lima dosen dan satu tim pengembang inklusi Jawa Timur. Data penelitian dikumpulkan melalui forum group discussion, angket dan dokumentasi yang dianalisis dengan teknik deskriptif kualitatif dan kuantitatif. Dari hasil penelitian diperoleh rumusan sepuluh kompetensi pengelolaan pembelajaran inklusi yang hendaknya dapat dikuasai mahasiswa calon guru SD. Hasil penelitian juga menunjukkan bahwa mayoritas mahasiswa Prodi PGSD UMM memiliki kesiapan yang baik dalam menguasai sepuluh kompetensi tersebut, antara lain $85 \%$ menguasai kriteria 1, 2, 3, 4, 7 dan 8; 65\% menguasai kriteria 5 dan 6; 80\% menguasai kriteria 9 dan 10.
\end{abstract}

Kata kunci: pengelolaan pembelajaran; anak berkebutuhan khusus (ABK); mahasiswa PGSD 


\section{PENDAHULUAN}

Standar kompetensi guru kelas SD/MI yang ditetapkan Direktorat Ketenagaan, Ditjen DIKTI Tahun 2006 dan Peraturan Menteri DIKNAS Nomor 16 tahun 2007 menerangkan guru Sekolah Dasar diharapkan memiliki kompetensi profesional yang salah satunya adalah kemampuan memahami perbedaan individual peserta didik, baik dari segi kognitif dan emosionalnya. Kompetensi guru sekolah dasar yang ditetapkan pemerintah tersebut ditujukan untuk mendidik dan mengelola pembelajaran siswa dalam klasifikasi normal. Namun faktanya, di sekolah dasar juga ditemui ada peserta didik memiliki kekurangan, kecacatan, kekurangmampuan atau hal lain yang disebut dengan Anak Berkebutuhan Khusus atau ABK (Widyawati, 2017). Anak berkebutuhan khusus (ABK) dalam konteks persekolahan diartikan sebagai anak yang mengalami perkembangan menyimpang dari kriteria normal, penyimpangan tersebut bisa dari aspek fisik, psikis, emosi maupun sosial. Peserta didik tersebut membutuhkan pelayanan khusus untuk mengembangkan dan melaksanakan proses pembelajaran sesuai potensinya (Kusumasari dkk., 2018; Mahabbati, 2010).

Urgensi pelayanan bagi ABK diwujudkan dalam perubahan sistem pendidikan untuk anak berkebutuhan khusus melalui program pendidikan inklusi yang tertuang dalam Permendikbud Nomor 70 tahun 2009. Pada program tersebut dijelaskan bahwa ABK dididik bersama-sama anak normal di sekolah reguler dengan pertimbangan pemerataan dan mengoptimalkan potensinya melalui pelayanan pendidikan inklusi (Darma \& Rusyidi, 2015; Kadir, 2016). Program pendidikan inklusi ini dilandasi kenyataan bahwa dalam masyarakat terdapat peserta didik normal dan ABK yang tidak dapat dipisahkan sebagai suatu komunitas (Cieza \& Bickenbach, 2015). ABK perlu diberi kesempatan dan peluang yang sama dengan anak normal untuk mendapatkan pelayanan pendidikan di sekolah dasar terdekat. Idealnya sekolah menerapkan tiga prinsip pembelajaran ABK antara lain (1) pengenalan dini untuk mendeteksi dan penanganan penyimpangan perkembangan peserta didik sejak dini, (2) optimalisasi potensi untuk menemukan dan mengoptimalkan kelebihan atau potensi khusus peserta didik, (3) kemandirian untuk mempersiapkan peserta didik agar dapat hidup mandiri sesuai potensi dan kemampuan yang dimiliki (Degener, 2017).

Khususnya pada sekolah dasar inklusi, yakni sekolah dasar yang ditunjuk secara khusus untuk mampu memberikan layanan pembelajaran bagi ABK. Idealnya, di setiap sekolah dasar inklusi ini memiliki Guru Pendamping Khusus (GPK) untuk memberikan bantuan pembelajaran pada ABK pada kelas reguler dan kelas khusus. Berbanding terbalik dengan kondisi ideal, hasil temuan penelitian menunjukkan bahwa tidak semua sekolah dasar Inklusi memiliki GPK sehingga tanggungjawab pembelajaran juga dibebankan kepada guru kelas (Jesslin \& Kurniawati, 2020). Hal ini memunculkan persoalan tersendiri bahwa nyatanya tidak semua guru di sekolah reguler dipersiapkan secara khusus untuk dapat memberikan pelayanan pendidikan inklusi (Anjarsari, 
2018). Persoalan lain juga terdapat pada keterbatasan saranan dan prasarana serta belum maksimalnya pengelolaan pendidikan inklusi di sekolah (Agustin, 2019; Rachman, 2020). Pengelolaan pembelajaran di sekolah dasar inklusi masih sangat bervariasi bergantung pada kebijakan masing-masing sekolah (Eriksson dkk., 2007; Triyanto \& Permatasari, 2016).

Dari persoalan yang muncul dalam implementasi program pendidikan inklusi di sekolah dasar, kesiapan guru sekolah dasar dalam mengelola pembelajaran inklusi perlu untuk mendapatkan perhatian khusus. Perlu adanya tindakan atau kondisi khusus untuk memberikan bekal pengetahuan dan keterampilan dalam mengelola pembelajaran ABK. Salah satunya pada Program Studi PGSD Universitas Muhammadiyah Malang (UMM) yang mengembangkan dan menerapkan kelompok mata kuliah $\mathrm{ABK}$ sebagai mata kuliah wajib untuk mahasiswa. Pengembangan ini dilatarbelakangi kebutuhan lapangan dan hasil tracer study yang menunjukkan bahwa kompetensi pengelolaan pendidikan inklusi di sekolah sangat diperlukan. Penerapannya diwujudkan melalui tiga capaian pembelajaran antara lain (1) memiliki pemahaman tentang siapa ABK, (2) memahami bagaimana ABK belajar, dan (3) memiliki kemampuan untuk membelajarkan ABK. Kompetensi tersebut menjadi kompetensi tambahan disamping kompetensi utama mahasiswa calon guru profesional sebagai pendidik, peneliti pembelajaran, dan praktisi pendidikan di sekolah dasar.

Kurikulum yang diterapkan bertujuan untuk meningkatkan kompetensi lulusan dalam memenuhi tanggung jawab profesionalnya apabila harus memberikan layanan pendidikan inklusi. Pada kondisi seperti ini, diharapkan mahasiswa calon guru sekolah dasar dapat melakukan identifikasi dini dengan benar, memberikan penanganan secara tepat, serta menetapkan langkah lanjutan bila diperlukan kerjasama ataupun meminta bantuan layanan kepada tenaga profesional dalam mengoptimalkan perkembangan ABK. Berdasarkan penerapan kurikulum unggulan di Prodi PGSD UMM ini, penelitian ini ditujukan untuk mendeskripsikan kompetensi ideal guru sekolah dasar dalam mengelola pembelajaran $\mathrm{ABK}$ di sekolah inklusi dan mendeskripsikan kesiapan mahasiswa PGSD UMM dalam mengelola pembelajaran ABK berdasarkan kompetensi tersebut. Penelitian ini diharapkan dapat menjadi rujukan dalam mempersiapkan mahasiswa lulusan Prodi PGSD UMM mencapai kompetensi unggulan sebagai guru SD yang mampu mengelola pembelajaran ABK di sekolah inklusi.

\section{METODE}

Penelitian ini menggunakan pendekatan mixed method dengan mengkombinasikan metode pendekatan kuantitatif dengan kualitatif. Penelitian dilaksanakan pada semester genap tahun ajaran 2019/2020 di Program Studi PGSD UMM. Subjek penelitian ini adalah satu tim pengembang sekolah inklusi Jawa Timur, lima anggota tim dosen pembelajaran ABK, dan 300 mahasiswa 
PGSD semester enam yang telah menempuh semua mata kuliah inklusi. Pengumpulan data dilakukan secara simultan melalui focus group discussion (FGD), angket, dan dokumentasi yang secara rinci disajikan pada Tabel 1.

Tabel 1.Teknik Pengumpulan, Data, dan Sumber Data Penelitian

\begin{tabular}{|c|c|c|c|}
\hline No & Teknik & Data & Sumber Data \\
\hline 1 & FGD & $\begin{array}{l}\text { - Data kompetensi guru dalam } \\
\text { pengelolaan pembelajaran ABK di } \\
\text { sekolah inklusi }\end{array}$ & $\begin{array}{l}\text { - Tim pengembang sekolah inklusi } \\
\text { Jawa Timur \& lima anggota tim } \\
\text { dosen pembelajaran ABK }\end{array}$ \\
\hline 2 & Angket & $\begin{array}{l}\text { - Data kesiapan mahasiswa dalam } \\
\text { pengelolaan pembelajaran ABK di } \\
\text { sekolah inklusi }\end{array}$ & $\begin{array}{l}\text { - } 300 \text { mahasiswa PGSD semester } \\
\text { enam yang telah menempuh semua } \\
\text { mata kuliah pembelajaran ABK }\end{array}$ \\
\hline 3 & Dokumentasi & $\begin{array}{l}\text { - Data dokumen kurikulum kelompok } \\
\text { mata kuliah inklusi dan pedoman } \\
\text { kompetensi pembelajaran ABK di } \\
\text { sekolah inklusi }\end{array}$ & $\begin{array}{l}\text { - Dokumen kurikulum dan perangkat } \\
\text { pembelajaran kelompok mata kuliah } \\
\text { inklusi }\end{array}$ \\
\hline
\end{tabular}

Data penelitian dianalisis dengan teknik analisis deskriptif kualitatif untuk menganalisis data hasil FGD dan analisis isi kurikulum kelompok mata kuliah ABK terkait kesesuaiannya dengan kompetensi yang dibutuhkan di lapangan dan data dokumentasi perangkat pembelajaran. Dilanjutkan dengan Teknik analisis deskriptif kuantitatif untuk menganalisis tingkat kesiapan mahasiswa dalam mengelola pembelajaran ABK, dilanjutkan dengan teknik analisis deskriptif. Prosedur penelitian dilaksanakan dalam lima tahap yang diuraikan sebagai berikut. Pertama, pelaksanaan FGD dengan tim pengembang sekolah inklusi provinsi Jawa Timur dan tim dosen mata kuliah pembelajaran ABK terkait dengan kompetensi yang dibutuhkan di lapangan untuk mengelola pembelajaran ABK. Kedua, pelaksanaan curriculum content analysis dengan menganalisis silabus dan perangkat pembelajaran yang sudah dikembangkan oleh dosen rumpun mata kuliah inklusi. Ketiga, penyusunan instrumen angket untuk mahasiswa dari hasil kegiatan tahap sebelumnya yang terdiri dari 40 item, angket dikembangkan dari materi pengetahuan dan keterampilan yang harus dikuasai pada kelompok mata kuliah ABK sehingga memenuhi kriteria validitas isi. Keempat, pengumpulan data melalui angket untuk mengungkap tingkat kesiapan mahasiswa Prodi PGSD UMM dalam mengelola pembelajaran ABK. Kelima, pengolahan data dan pelaporan untuk memaparkan kesiapan mahasiswa Prodi PGSD UMM dalam mengelola pembelajaran ABK di sekolah inklusi.

\section{HASIL DAN PEMBAHASAN}

\section{Kompetensi Guru dalam Pengelolaan Pembelajaran ABK di Sekolah Inklusi}

Data hasil FGD dosen dengan tim pengembang sekolah inklusi provinsi Jawa Timur dapat diidentifikasi adanya 14 kompetensi yang harus dimiliki oleh guru sekolah inklusi yang diuraikan pada Tabel 2 . 
Tabel 2. Kompetensi Guru Sekolah Inklusi

\begin{tabular}{|c|c|c|}
\hline No & Kompetensi & Deskripsi \\
\hline 1 & $\begin{array}{l}\text { Memahami konsep pendidikan } \\
\text { inklusif }\end{array}$ & $\begin{array}{l}\text { - Mencakup kemampuan dalam memahami sejarah } \\
\text { Pendidikan inklusi, landasan filosofi dan teori, dasar } \\
\text { hukum baik internasional maupun nasional }\end{array}$ \\
\hline 2 & Memahami konsep ABK & $\begin{array}{l}\text { - Meliputi definisi anak berkebutuhan khusus, dasar teori } \\
\text { kebutuhan khusus, termasuk di dalamnya memahami } \\
\text { jenis jenis ABK, kategorisasi, dan layanan Pendidikan } \\
\text { yang dibutuhkan }\end{array}$ \\
\hline 3 & $\begin{array}{l}\text { Memahami konsep dan ciri-ciri anak } \\
\text { penyandang ketunaan }\end{array}$ & $\begin{array}{l}\text { - Meliputi anak dengan kecerdasan dan bakat istimewa, } \\
\text { pada kompetensi ini ditekankan pada pemahaman guru } \\
\text { terhadap karakteristik belajar, ciri perkembangan dan } \\
\text { partisipasi sosial dari setiap jenis ketunaan serta anak } \\
\text { dengan kecerdasan dan atau bakat istimewa }\end{array}$ \\
\hline 4 & $\begin{array}{l}\text { Memahami kerja tim dan sistem } \\
\text { dukungan (support system) dalam } \\
\text { penyelenggaraan pendidikan inklusif }\end{array}$ & $\begin{array}{l}\text { - Meliputi pemahaman tentang mekanisme dukungan dan } \\
\text { rujukan dalam penyelenggaraan pendidikan inklusif }\end{array}$ \\
\hline 5 & $\begin{array}{l}\text { Mengidentifikasi anak penyandang } \\
\text { ketunaan }\end{array}$ & $\begin{array}{l}\text { - Melakukan identifikasi dini bila dikelasnya ditengarai } \\
\text { ada yang mengalami perkembangan menyimpang, } \\
\text { dengan menggunakan instrumen identifikasi untuk anak } \\
\text { penyandang ketunaan }\end{array}$ \\
\hline 6 & $\begin{array}{l}\text { Memahami konsep asesmen bagi } \\
\text { anak penyandang ketunaan, }\end{array}$ & $\begin{array}{l}\text { - Meliputi konsep, dasar teori, jenis-jenis asesmen dan } \\
\text { metode-metode asesmen yang diperlukan dalam } \\
\text { melakukan asesmen untuk anak penyandang ketunaan }\end{array}$ \\
\hline 7 & $\begin{array}{l}\text { Membaca dan memahami hasil } \\
\text { asesmen dari profesional lain, }\end{array}$ & $\begin{array}{l}\text { - Memahami hasil asesmen formal, misalnya dari dokter } \\
\text { THT, Psikolog, Psikiater, dan Dokter Mata. }\end{array}$ \\
\hline 8 & $\begin{array}{l}\text { Menyusun instrumen asesmen } \\
\text { informal untuk anak berkebutuhan } \\
\text { khusus }\end{array}$ & $\begin{array}{l}\text { - Mencakup asesmen perkembangan maupun asesmen } \\
\text { akademik untuk anak penyandang ketunaan }\end{array}$ \\
\hline 9 & Melakukan praktek asesmen & $\begin{array}{l}\text { - Meliputi area perkembangan maupun akademik dari } \\
\text { instrumen yang dibuatnya sendiri, termasuk di } \\
\text { dalamnya menyusun laporan asesmen informal }\end{array}$ \\
\hline 10 & Menyelenggarakan diskusi kasus & - Khususnya dengan melibatkan tim yang multi disiplin \\
\hline 11 & Penyesuaian pembelajaran & $\begin{array}{l}\text { - Mencakup dasar teori, prinsip-prinsip modifikasi } \\
\text { pembelajaran sesuai kebutuhan anak berkebutuhan } \\
\text { khusus }\end{array}$ \\
\hline 12 & $\begin{array}{l}\text { Membuat silabus dan rencana } \\
\text { pembelajaran modifikasi }\end{array}$ & $\begin{array}{l}\text { - Penyusunan disesuaikan dengan kondisi anak } \\
\text { berkebutuhan khusus di kelasnya }\end{array}$ \\
\hline 13 & $\begin{array}{l}\text { Praktek mengajar di kelas reguler } \\
\text { dengan anak berkebutuhan khusus di } \\
\text { dalamnya }\end{array}$ & $\begin{array}{l}\text { - Praktek mengajar dalam latar yang sesungguhnya, } \\
\text { sehingga yang dibutuhkan adalah program } \\
\text { pendampingan atau on job training }\end{array}$ \\
\hline 14 & Layanan kompensatoris & $\begin{array}{l}\text { - Memberikan kompensatoris disesuaikan dengan } \\
\text { ketunaan yang disandang anak, misalnya bina diri, } \\
\text { orientasi mobilitas, bina gerak dan sebagainya }\end{array}$ \\
\hline
\end{tabular}

Kompetensi yang dipersyaratkan untuk menjadi guru ABK di sekolah inklusi tersebut menunjukkan adanya tuntutan yang cukup komprehensif dalam kemampuan mengelola pembelajaran $\mathrm{ABK}$, yang kemungkinan terlalu berat bagi guru kelas, lulusan PGSD, karena dapat dilihat bahwa kompetensi ini hampir sama dengan tuntutan kompetensi untuk GPK yang memang secara khusus disiapkan menjadi guru ABK (Nurvitasari dkk., 2018). GPK yang ada di sekolah dasar, pada umumnya adalah guru alumni program Studi Pendidikan Luar Biasa, sedang alumni Program Studi Pendidikan Guru Sekolah Dasar yang berasal dari PGSD disiapkan sebagai guru kelas sekaligus guru mata pelajaran yang ada di Sekolah Dasar (Wati, 2014). Implementasi 
tuntutan kompetensi unggulan dalam mengelola pembelajaran ABK lebih ditekankan untuk dapat melakukan identifikasi dini bila di kelasnya ada anak anak yang diindikasi memiliki perkembangan menyimpang, dan melakukan modifikasi pembelajaran untuk mengoptimalkan potensi peserta didik di kelas termasuk ABK sehingga dibutuhkan kerjasama dengan tim ahli yang baik (Elnurianda dkk., 2018).

Selaras dengan data analisis kurikulum yang menunjukkan bahwa sejak tahun 2007 PGSDUMM telah mencanangkan unggulan pendidikan kesetaraan dengan menetapkan pendidikan Inklusi sebagai mata kuliah wajib. Hal ini dilatarbelakangi berbagai kasus perkembangan menyimpang pada peserta didik yang membutuhkan kompetensi guru dalam melakukan diagnostik dan penanganan di kelas. Sesuai hasil tracer study pada alumni dan kebutuhan stakeholder yang menunjukkan banyaknya sekolah yang meminta lulusan yang memiliki bekal pembelajaran ABK. Kebijakan yang diambil adalah dengan mewajibkan semua mahasiswa PGSD mulai angkatan 2015 menempuh semua kelompok mata kuliah pembelajaran ABK. Pada tahun 2016 kelompok mata kuliah pembelajaran $\mathrm{ABK}$ dirumuskan menjadi mata kuliah pendidikan $\mathrm{ABK}$, asesmen $\mathrm{ABK}$, pembelajaran ABK 1, dan pembelajaran ABK 2 dengan jumlah 8 SKS untuk keseluruhannya. Berpijak dari hasil FGD dan analisis isi kurikulum dirumuskan sepuluh kompetensi dalam pengelolaan pembelajaran ABK bagi mahasiswa calon guru pada Tabel 3. untuk mengungkap kesiapan mahasiswa dalam mengelola pembelajaran ABK memenuhi pertimbangan content validity.

\section{Kesiapan Mahasiswa dalam Pengelolaan Pembelajaran ABK di Sekolah Inklusi}

Dari sepuluh kompetensi yang dirumuskan dikembangkan angket kesiapan mahasiswa dalam pengelolaan pembelajaran ABK yang terdiri 40 item pertanyaan kepada 300 mahasiswa sebagai subjek dalam penelitian ini. Hasil analisis kesiapan mahasiswa dalam pengelolaan pembelajaran ABK di sekolah inklusi menunjukkan bahwa penguasaan kompetensi mahasiswa berada pada rentang persentase $65 \%-85 \%$. Sajian persentase penguasaan pada setiap indikator dapat diamati pada Tabel 4.

Hasil analisis angket pada 300 mahasiswa semester 6 menunjukkan bahwa dari 10 kompetensi guru mengelola pembelajaran untuk ABK di sekolah dasar tersebut, ada 6 kompetensi dapat dikuasai mahasiswa dengan baik, hal ini dapat diketahui karena lebih dari $85 \%$ mahasiswa (255 mahasiswa) yang menyatakan telah menguasai dengan baik dan 15\% (45 mahasiswa) menyatakan belum menguasai untuk kompetensi tentang kebijakan pendidikan inklusi (K1), mengenali siapa $\mathrm{ABK}$ (K2), identifikasi $\mathrm{ABK}$ (K3), pemahaman asesmen (K4), menyusun laporan asesmen (K7), dan pengembangan program pembelajaran individual (K8). Perlu dijelaskan lebih lanjut bahwa keenam kompetensi diatas lebih banyak didasarkan pada kemampuan kognitif dan banyak diperoleh pemahamannya dalam pembelajaran di dalam kelas. 
Tabel 3. Kemampuan Guru Sekolah Reguler Penyelenggara Pendidikan Inkluksif

\begin{tabular}{|c|c|c|c|c|c|}
\hline Kode & Kompetensi & CP1 & CP2 & CP3 & Deskripsi Kompetensi \\
\hline K1 & $\begin{array}{l}\text { Kebijakan } \\
\text { Pendidikan Inklusi }\end{array}$ & $\sqrt{ }$ & & & $\begin{array}{l}\text { - Menguasai kebijakan pemerintah, kebijakan } \\
\text { daerah, dukungan kebijakan di sekolah }\end{array}$ \\
\hline $\mathrm{K} 2$ & $\begin{array}{l}\text { Mengenali Siapa } \\
\text { ABK }\end{array}$ & $\sqrt{ }$ & & & $\begin{array}{l}\text { - Menguasai pengertian siapa ABK, ciri dan } \\
\text { karakteristik ABK, faktor penyebab ABK, upaya } \\
\text { optimalisasi perkembangan ABK }\end{array}$ \\
\hline $\mathrm{K} 3$ & Identifikasi ABK & $\sqrt{ }$ & & & $\begin{array}{l}\text { Menguasai identifikasi dini, mengenal instrumen } \\
\text { identifikasi ABK, latihan Penggunaan Instrumen } \\
\text { identifikasi dini }\end{array}$ \\
\hline $\mathrm{K} 4$ & $\begin{array}{l}\text { Pemahaman } \\
\text { Asesmen }\end{array}$ & & $\sqrt{ }$ & & $\begin{array}{l}\text { - Menguasai konsep dasar identifikasi ABK, } \\
\text { konsep dasar asesmen, ruang Lingkup asesmen } \\
\text { bagi ABK, pengembangan instrumen asesmen, } \\
\text { layanan penempatan, layanan referal }\end{array}$ \\
\hline K5 & $\begin{array}{l}\text { Layanan Asesmen } \\
\text { Akademik }\end{array}$ & & $\sqrt{ }$ & & $\begin{array}{l}\text { Menguasai asesmen berasaskan kurikulum } \\
\text { (asesmen akademik), asesmen membaca, } \\
\text { asesmen matematika, asesmen menulis }\end{array}$ \\
\hline K6 & $\begin{array}{l}\text { Layanan Asesmen } \\
\text { Perkembangan }\end{array}$ & & $\sqrt{ }$ & & $\begin{array}{l}\text { - Menguasai asesmen berdasarkan perkembangan } \\
\text { (asesmen non akademik), asesmen } \\
\text { perkembangan persepsi (visual, auditif, } \\
\text { kinestetik, taktil), asesmen perkembangan } \\
\text { motorik (gross motor, fine motor, balance, } \\
\text { coordination), asesmen perkembangan bahasa } \\
\text { (receptive language and expressive language) }\end{array}$ \\
\hline K7 & Laporan Asesmen & & $\sqrt{ }$ & & $\begin{array}{l}\text { - Menyusun laporan asesmen dan studi kasus } \\
\text { ABK }\end{array}$ \\
\hline K8 & $\begin{array}{l}\text { Pengembangan } \\
\text { Program } \\
\text { Pembelajaran } \\
\text { Individual }\end{array}$ & & & $\sqrt{ }$ & $\begin{array}{l}\text { Menguasai hakikat program pembelajaran } \\
\text { individual bagi ABK, prinsip-prinsip PPI, } \\
\text { prosedur penyusunan PPI }\end{array}$ \\
\hline K9 & $\begin{array}{l}\text { Modifikasi } \\
\text { Kurikulum }\end{array}$ & & & $\sqrt{ }$ & $\begin{array}{l}\text { Menguasai orientasi pada kurikulum, modifikasi } \\
\text { kurikulum, menentukan indikator keberhasilan, } \\
\text { menentukan instrumen evaluasi ABK, } \\
\text { mengembangkan soal }\end{array}$ \\
\hline K10 & $\begin{array}{l}\text { Memahami } \\
\text { Pembelajaran } \\
\text { ABK }\end{array}$ & & & $\sqrt{ }$ & $\begin{array}{l}\text { Menguasai layanan kompensatoris anak tuna } \\
\text { netra, tunarungu, tunaganda, tunadaksa, autis; } \\
\text { Menyusun PPI berdasarkan hasil asesmen yang } \\
\text { sudah dilakukan dikaitkan dengan program } \\
\text { kompensatoris ABK; Praktik (simulasi) hasil } \\
\text { penyusunan PPI }\end{array}$ \\
\hline
\end{tabular}

Tabel 4. Persentase Penguasaan Kompetensi Mahasiswa

\begin{tabular}{crrrr}
\hline Kompetensi & \multicolumn{4}{c}{ Penguasaan Kompetensi Mahasiswa } \\
\hline Menguasai & \% & Belum Menguasai & $\%$ \\
K2 & 255 & 85 & 45 & 15 \\
K3 & 255 & 85 & 45 & 15 \\
K4 & 255 & 85 & 45 & 15 \\
K5 & 255 & 85 & 45 & 15 \\
K6 & 195 & 65 & 105 & 35 \\
K7 & 195 & 65 & 105 & 35 \\
K8 & 255 & 85 & 45 & 15 \\
K9 & 255 & 85 & 45 & 15 \\
K10 & 240 & 80 & 60 & 20 \\
\hline
\end{tabular}


Terdapat 65\% (195 mahasiswa) menyatakan telah menguasai dan 35\% (105 mahasiswa) menyatakan belum dapat menguasai pengetahuan dan keterampilan dalam kompetensi layanan asesmen akademik (K5) dan layanan asesmen perkembangan (K6). Penguasaan dua kompetensi ini harusnya dapat dioptimalkan dengan memberikan kesempatan mahasiswa untuk mempraktekkan pengetahuan dan keterampilan tersebut di kelas inklusi (Rahmawati, 2018). Praktik yang dimaksud mencakup asesmen pengembangan kapasitas diri yang penting untuk dikuasai mahasiswa calon guru dalam pembelajaran ABK (Nurwahidah, 2017). Selanjutnya Terdapat $80 \%$ (240 mahasiswa) menyatakan telah menguasai dan 20\% (60 mahasiswa) menyatakan belum menguasai karena menganggap materi sulit dan perlu pendalaman dengan lebih banyak praktek yaitu pada model model pembelajaran ABK utamanya pembelajaran kompensatoris (K9) dan modifikasi kurikulum (K10). Secara lebih khusus mahasiswa merasa masih kurang paham dalam mengembangkan instrumen evaluasi hasil belajar untuk $\mathrm{ABK}$, karena pada sub kompetensi ini mahasiswa mulai dituntut untuk dapat melihat potensi positif yang dimiliki oleh ABK (Rudiyati, 2013).

Dari data tingkat penguasaan ini, juga diperoleh data dari dosen kelompok mata kuliah ABK yang menyatakan bahwa banyaknya jumlah mahasiswa perkelas dapat menjadi penyebab mahasiswa mengalami kesulitan untuk mendapatkan waktu yang cukup dan tempat praktek di sekolah inklusi. Kondisi ini berdampak beberapa mahasiswa tidak memperoleh kesempatan yang cukup untuk dapat melakukan praktek keterampilan, identifikasi perilaku, melaksanakan asesmen, dan kesempatan untuk mempraktekkan pembelajaran di kelas nyata. Kesempatan praktik yang lebih banyak akan membuat mahasiswa lebih menguasai pengetahuan dan keterampilan sesuai hasil penelitian. Hapsari \& Widhianningrum (2016) yang menunjukkan bahwa guru yang memiliki pengalaman praktik mengajar lebih terampil dibanding guru yang lebih sedikit pengalaman praktiknya. Hasil penelitian lain juga menjelaskan bahwa kemajuan teknologi informasi dan social media serta perubahan pola kehidupan masyarakat menyebabkan semakin banyak peserta didik di sekolah yang menunjukkan indikasi perkembangan menyimpang, seperti anak yang sangat emosional, anak yang tidak peduli pada lingkungan, atau sangat individualistis (Heni \& Mujahid, 2018; Syifa dkk., 2019). Berpijak dari fakta ini, semakin diperlukan guru di sekolah dasar yang memiliki kemampuan penanganan pembelajaran ABK khususnya dalam melakukan identifikasi dan pengenalan dini terhadap peserta didik yang membutuhkan penanganan secara khusus.

\section{SIMPULAN DAN SARAN}

\section{Simpulan}

Berdasarkan hasil penelitian disimpulkan bahwa terdapat sepuluh kompetensi pengelolaan pembelajaran $\mathrm{ABK}$ hendaknya dikuasai mahasiswa calon guru sekolah dasar. Kompetensi tersebut antara lain (1) kebijakan pendidikan inklusi, (2) mengenali siapa ABK, (3) mengidentifikasi ABK, 
(4) memiliki pemahaman asesmen $\mathrm{ABK}$, (5) memberikan layanan asesmen akademik, (6) memberikan layanan asesmen perkembangan, (7) menyusun laporan asesmen, (8) mengembangkan program pembelajaran individual, (9) memodifikasi kurikulum, (10) memahami pembelajaran ABK. Sepuluh kompetensi tersebut digunakan untuk menggali data kesiapan mahasiswa Prodi PGSD UMM dalam pengelolaan pembelajaran ABK. Kesiapan mahasiswa Prodi PGSD UMM dalam pengelolaan pembelajaran ABK menunjukkan bahwa mayoritas mahasiswa memiliki penguasaan kompetensi yang baik. Penguasaan kompetensi 1, 2, 3, 4, 7, dan 8 mencapai 85\% sebanyak 276 mahasiswa menyatakan menguasai kompetensi tersebut. Penguasaan kompetensi 5 dan 6 mencapai 65\% sebanyak 192 mahasiswa menyatakan menguasai kompetensi tersebut. Penguasaan kompetensi 9 dan 10 mencapai 80\% sebanyak 232 mahasiswa menyatakan menguasai kompetensi tersebut.

\section{Saran}

Hasil penelitian ini diharapkan dapat dijadikan landasan bagi Program Studi PGSD UMM dalam meninjau ulang dan melakukan rekonstruksi isi kurikulum terkait kompetensi dan substansi materi kelompok mata kuliah pembelajaran ABK. Khususnya untuk pengampu mata kuliah ABK dapat melakukan revisi Rencana Pembelajaran Semester (RPS) dan menyusun bahan ajar kelompok mata kuliah pendidikan $\mathrm{ABK}$ sesuai kompetensi pengelolaan pembelajaran $\mathrm{ABK}$ di sekolah inklusi untuk memfasilitasi belajar dan praktik mahasiswa dalam pembelajaran inklusi.

\section{DAFTAR RUJUKAN}

Agustin, I. (2019). Permasalahan dalam Penyelenggaraan Pendidikan Inklusi di SDN Se Kecamatan Soko Kabupaten Tuban. ELSE (Elementary School Education Journal): Jurnal Pendidikan Dan Pembelajaran Sekolah Dasar, 3(2). https://doi.org/10.30651/else.v3i2.3104

Anjarsari, A. D. (2018). Penyelenggaraan Pendidikan Inklusi Pada Jenjang SD, SMP, dan SMA di Kabupaten Sidoarjo. JPI (Jurnal Pendidikan Inklusi), 1(2), 91. https://doi.org/10.26740/inklusi.v1n2.p91-104

Cieza, A., \& Bickenbach, J. E. (2015). Functioning, Disability and Health, International Classification of. In International Encyclopedia of the Social \& Behavioral Sciences: Second Edition. https://doi.org/10.1016/B978-0-08-097086-8.14081-4

Darma, I. P., \& Rusyidi, B. (2015). Pelaksanaan Sekolah Inklusi di Indonesia. Prosiding Penelitian dan Pengabdian Kepada Masyarakat, 2(2). https://doi.org/10.24198/jppm.v2i2.13530

Degener, T. (2017). 10 years of convention on the rights of persons with disabilities. Netherlands Quarterly of Human Rights. https://doi.org/10.1177/0924051917722294

Elnurianda, F., Fauzan, U., \& Hamzah, S. H. (2018). The Implementation of Islamic Education Teaching at Inclusive Schools in Samarinda, East Kalimantan. MADANIA: Jurnal Kajian Keislaman, 22(2), 173. https://doi.org/10.29300/madania.v22i2.1273 
Eriksson, L., Welander, J., \& Granlund, M. (2007). Participation in everyday school activities for children with and without disabilities. Journal of Developmental and Physical Disabilities, 19(5). https://doi.org/10.1007/s10882-007-9065-5

Hapsari, P., \& Widhianningrum, P. (2016). Pengaruh Praktik Pengalaman Lapangan Terhadap Kinerja Mahasiswa Calon Guru. Journal of Accounting and Business Education, 2(1). https://doi.org/10.26675/jabe.v2i1.6050

Heni, H., \& Mujahid, A. J. (2018). Pengaruh Penggunaan Smartphone terhadap Perkembangan Personal Sosial Anak Usia Pra-Sekolah. Jurnal Keperawatan Silampari, 2(1), 330-342. https://doi.org/10.31539/jks.v2i1.341

Jesslin, J., \& Kurniawati, F. (2020). Perspektif Orangtua terhadap Anak Berkebutuhan Khusus di Sekolah Inklusif. JPI (Jurnal Pendidikan Inklusi), 3(2). https://doi.org/10.26740/inklusi.v3n2.p72-91

Kadir, Abd. (2016). Penyelenggaraan Sekolah Inklusi Di Indonesia. Jurnal Pendidikan Agama Islam (Journal of Islamic Education Studies), 3(1), 1. https://doi.org/10.15642/jpai.2015.3.1.1-22

Kusumasari, D., Junaedi, D., \& Kaburuan, E. R. (2018). Designing an interactive learning application for ADHD children. MATEC Web of Conferences, 197, 16008. https://doi.org/10.1051/matecconf/201819716008

Mahabbati, A. (2010). Pendidikan Inklusif untuk Anak dengan Gangguan Emosi dan Perilaku (Tunalaras). Jurnal Pendidikan Khusus, 7(2), 52-63.

Nurvitasari, S., Azizah, L. Z., \& Sunarno, S. (2018). Konsep dan Praktik Pendidikan Inklusi di Sekolah Alam Ramadhani Kediri. Indigenous: Jurnal Ilmiah Psikologi, 3(1), 15-22. https://doi.org/10.23917/indigenous.v3i1.5743

Nurwahidah, I. (2017). Penggunaan Asesmen Pembelajaran Ipa Bagi Siswa Visual Impairment di SLB Jawa Tengah. JIPVA (Jurnal Pendidikan IPA Veteran), I(1), 39. https://doi.org/10.31331/jipva.v1i1.517

Rachman, R. F. (2020). Kebijakan Pendidikan Anak Berkebutuhan Khusus di Surabaya dalam Perspektif Islam. Bidayatuna: Jurnal Pendidikan Guru Mandrasah Ibtidaiyah, 3(1). https://doi.org/10.36835/bidayatuna.v3i01.518

Rahmawati, A. (2018). Konsep Pembelajaran PAI bagi Anak Berkebutuhan Khusus di Sekolah Inklusi: Studi Kasus di SD Semai Jepara. Edukasia Islamika, 171. https://doi.org/10.28918/jei.v3i2.1686

Rudiyati, S. (2013). Substansi Komponen Kompetensi Guru Sekolah Inklusif Bagi Anak Berkelainan/Berkebutuhan Pendidikan Khusus. Jurnal Penelitian Dan Evaluasi Pendidikan, 16(2), 533-552. https://doi.org/10.21831/pep.v16i2.1130

Syifa, L., Setianingsih, E. S., \& Sulianto, J. (2019). Dampak Penggunaan Gadget terhadap Perkembangan Psikologi pada Anak Sekolah Dasar. Jurnal Ilmiah Sekolah Dasar, 3(4), 538. https://doi.org/10.23887/jisd.v3i4.22310

Triyanto, T., \& Permatasari, D. R. (2016). Pemenuhan Hak Anak Berkebutuhan Khusus di Sekolah Inklusi. Sekolah Dasar: Kajian Teori Dan Praktik Pendidikan, 25(2), 176-186. https://doi.org/10.17977/um009v25i22016p176

Wati, E. (2014). Manajemen Pendidikan Inklusi Di Sekolah Dasar Negeri 32 Kota Banda Aceh. Jurnal Ilmiah Didaktika, 14(2). https://doi.org/10.22373/jid.v14i2.508

Widyawati, R. (2017). Evaluasi Pelaksanaan Program Inklusi Sekolah Dasar. Kelola: Jurnal Manajemen Pendidikan, 4(1), 109. https://doi.org/10.24246/j.jk.2017.v4.i1.p109-120 